\title{
Violence of Values/Values of Violence. The Cultural Struggle of Alt-Right Politics
}

\author{
NURIA SANCHEZ MADRID ${ }^{1}$ \\ Faculty of Philosophy, Complutense University of Madrid, Av. Séneca, 2, 28040 Madrid, Spain \\ Email:nuriasma@ucm.es
}

\begin{abstract}
This paper tackles the construction of social and political values that contemporary Alt-Right politics foster. Its aim will be, first, to tackle the values that Alt-Right parties are spreading at a global scale from the last decade. Second, I will focus on how they address the most precarious social groups for increasing their supporters and how they have built a new model of the social order that gainsays human and civil rights. Finally, I will give an account of some reasons that explain the social failure of classical Leftist political parties, also attempting to transform the ways they accost the former 'working class'. I engage a dialogue with Zeynep Gambetti and Vladimir Safatle, as both authors have centrally addressed the cultural struggle that populist right parties accomplish on a global scale.
\end{abstract}

Keywords: violence, sovereignty, interdependence, precarity, demos, Alt-Right

\section{INTRODUCTION}

The title of my paper voluntarily hints to the reluctance of values that Carl Schmitt uttered in his writing: the tyranny of values when they are addressed as a social bedrock. In his view, values would have overrun the space of politics as a consequence of the liberal mind, thus overthrowing the sovereign decision as the key concept of political action. Yet my main aim here shall not take direct issue with Schmitt's decisionism, embedded as it is in the so-called 'concrete order', an ideological stock which every social community should recognize as the source of its background of social norms and rules. Having made this prefatory remark, I consider it useful to take into account an assertion extracted from

1 Nuria Sánchez Madrid is Associate Professor at the Faculty of Philosophy of the University Complutense of Madrid. She is coordinator of the Complutense Research Group 'Normativity, Emotions, Discourse and Society' (970798) and of the Latin-American, Portuguese and Spanish Network 'Kant: Ethics, Politics and Society'. This paper has benefitted from the research granted by the research projects Digital Humanities awarded by the BBVA Foundation, On Trust-CM (H2019/HUM-5699) and UCM-Santander PR87/19-22633 Filosofía y pobreza. Una historia cultural de la exclusión social, and the Project for Teaching Innovation UCM 2019 n. ${ }^{\circ} 84$ Precariedad, exclusión social y diversidad funcional (discapacidad): lógicas y efectos subjetivos del sufrimiento social contemporáneo (II). I wish to thank two anonymous reviewers of the Journal Filosofija. Sociologija for their remarks and comments which were very helpful to work out the final draft of this paper. 
the referred paper of Schmitt, written in 1959 for a conference on legal philosophy organized in Germany by a former student, Ernst Fosrthoff. Schmitt affirms there that values just hint to 'systems of relations composed by points of view, standpoints and insights' (Schmitt 2010: 47), which prevent discerning which one among them is the most convenient.

Ensuing from this disavowal of alleged objective norms for the sake of emerging subjective and personal points of view, Schmitt attempts to warn Europe in economic and social recovery after the Post-War time that values increasingly raising and circulating in the public sphere have precisely triggered most of the conflicts in the continent, as they use in his view to arbitrarily draw a sharp slash between a friend and a foe. Thus the expansion of values gave Schmitt part of his own medicine, as he realized that the ideological construction of hostility was able to funnel political action in different ways, not just through norms but also through emotions and values. I especially assume from Schmitt his claim that contemporary politics has become an entangled field where discussion, negotiation and deliberation have overshadowed the function once assigned to naturalized tradition, duties and ethical order.

The aim of this paper will be, first, to tackle the political values that Alt-Right parties spread at a global scale in the last decade. Second, I will focus on how they address the most precarious social groups for increasing their supporters and how they have built a new model of the social order that gainsays human and civil rights. Finally, I will give an account of some reasons that explain the social failure of classical Leftist political parties, also attempting to make of interdependence the key value to accost the transformed 'working class'. Alt-Right movements began to gain influence in the political field in the United States and Europe as classical right-wing political parties fell into a hard crisis, as they showed their inability to meet the populist demands of welfare and political participation rights that street and square protests raised against what they considered an outdated institutional frame.

The success of Alt-Right ideology was confirmed as Donald Trump chose Stephen K. Bannon, former editor of the web outlet Breitbart News, as his Campaign CEO. Endorsing this ideological backdrop, Trump's Government did not hesitate to boost massive deportations of undocumented immigrants, to enforce protectionist trade models and to disavow feminist concerns and any diversity agenda, forgetting to abide with basic human and civil rights. According to Main, a recognized specialist in the intellectual roots of Alt-Right parties, this ideology 'is a kind of radical Gnosticism as fundamental in its rejection of the American Democratic tradition as the Communist Party line of the 1930s and the most fevered effusions of New Left radicalism of the 1960s were' (Main 2018: 7).

In the last years, a large number of essays devoted to survey the success of Alt-Right ideology appeared (Hawley 2017; Main 2018; Salazar 2018). Yet my paper will especially heed to the analyses of this ideological phenomenon that Zeynep Gambetti recently developed, which, in my view, display a blunt account of the social values transformation that Alt-Right political parties boost at a global scale. I will also take into account some recent papers by Vladimir Safatle that break down the cultural struggle that Alt-Right political movements and parties drive in different continents. I consider it helpful to highlight beforehand that social values, with their influence over the expectations and misgivings that the people have, change as shared social practices evolve. Moreover, the globally spread Alt-Right political parties discovered in recent years the power of reshaping the so-called common sense setting up a stage featuring fake news, xenophobia, hate, frustration and 
extended rebound which wide layers of society manifested to the institutional realm due to its unfulfilled tasks. ${ }^{2}$

Ensuing from this claim I would dare to affirm that reactionary populism devised in recent years its own path to reframe a kind of concrete order with the help of reactionary emotions, understood in a sense quite near to the functional meaning that Schmitt assigns to it. Actually, the elements composing a concrete order mostly draw to affective bonds and unwitting emotions, which are experienced, as though they were just the normative response to a matter of fact. Thus, I will try to highlight the historical plasticity of the ethical order that a society as a whole agrees with, drawing as conclusion that the construction of a web made of reciprocal mistrust, interests and expectations is the gist of what one might call a democratic ethos. Moreover, as according to an Adorno's claim that Rahel Jaeggi underscored in different papers there is no individual resistance against neoliberal forms of life ${ }^{3}$, democratic hope around the world should agree with Alt-Right spin-doctors at least regarding one thing, i.e. that the beliefs and reluctances we share engage our political life in both a discursive and bodily direction.

Thus, my paper takes inspiration from the fact that values have definitively superseded ancient social norms and theological based rules, opening an epoch where subjectivity reigns everywhere. Put slightly different, the struggle of doxai overthrew out-dated theological and metaphysical principles, giving way to a debate between post-Habermasian supporters of deliberative democracies and followers of Laclau's model of populism, which often outshine the emancipatory potential of radical democratic demands and movements.

\section{THE FALSE QUANDARY BETWEEN SOVEREIGNTY AND INTERDEPENDENCE}

The political upheavals of our time have largely confirmed that every common ground of beliefs and hopes has previously been framed by concrete social praxis. In this vein, I would argue that orotund terms as sovereignty, territorial identity and state-nation framework become more helpful at a global scale as they avow without reluctance their empirical and contingent genesis, highlighting that they stem from a concrete understanding of political pluralism and human coexistence and interdependence. Whereas sovereignty has been understood from Modern history onwards as the legitimate and controlled administration of violence, interdependence does not entail any guarantee to remove every manifestation of hostility among human beings. Yet whilst sovereignty concentrates all energies in shielding its own space allegedly surrounded by potential enemies, interdependence instead reveals which spaces should still be enabled for enlarging the concept of legal normativity and which devices might help to deceive resentment by transforming it in something more fruitful for the commonwealth.

2 The essays of Friberg (2015) might be considered as a sample of this construction of a new social deal which radically criticizes the harmful impact that the neoliberal model of market has on large social layers. The wide framework which this author draws on shares key conceptual milestones with the Marxist tradition, even if - for giving an example of Friberg's rationale - the emancipation of the alleged true members of the political community gets rid of the moral goal of solidarity.

3 With 'forms of life' I do not draw on the Aristotelian morally worthy life. Yet with this expression I hint to a new paradigm in social theory recently suggested by Rahel Jaeggi (2018) as a helpful means of resistance against the alleged neutral perspective adopted by the liberal tradition of social and political theory vis-à-vis the plurality of human customs and the consequent abstemiousness regarding the plurality of personal expectations about well-being and human development. 
Taking into account the contemporary anxieties that consider sovereignty as the most evident symptom of power (Catalonian and Scottish demands of independency could be referred as an example of this claim), I would suggest replacing the pervading claim for attaining sovereignty as the highest political right by a new social contract whose linchpin hints to awareness of social and political interdependence as a condition that no national unity might be free to disregard. Actually, to take such a standpoint will immediately shift our benchmarks from Rousseau and Kant to explorations of the social and political bonds endorsed by authors as Iris M. Young and Judith Butler. To put it differently, my attention to the escalation of violence - embodied by xenophobic and unsupportive emotions and behaviours - as a sort of political fuel will draw as a conclusion that to water down the modern claims of sovereignty into an unwitting but unavoidable cooperation among different social groups - by nationality, religion or language - could raise firm bulwarks against the global network of Alt-Right mottos. I would like to hint at this point to an excerpt from a recent essay by Judith Butler for further clarifying the shift of the dominating axis throughout modern political theory:

' $[\mathrm{P}]$ recarity is the condition against which several new social movements struggle, such movements do not seek to overcome interdependency or even vulnerability as they struggle against precarity; rather, they seek to produce the condition under which vulnerability and interdependency become livable. This is a politics in which performative action takes bodily and plural form, drawing critical attention to the conditions of bodily survival, persistence, and flourishing within the framework of radical democracy' (Butler 2017: 218).

Recalling Schmitt's reluctance to values, which I mentioned at the outset of my paper, Butler helps us to understand that the attention driven in the past to the unity of a territory as a symbol of the general will has been transformed in the present in the recognition of linguistic, cultural and political plurality as a condition that none projected homogeneity of the social space could overshadow. Thus, the distinction between survival and good life returns to the centre of the public discussion, hampering as it does the spread of contemporary bio-politics, insofar as according to the second one - the construction of a good life - the attention to the material conditions of livability is expected to steadily guide political action. This claim might sound as an obvious outcome of the 20th century, but some past political experiences - as the democratic polis - should not be neglected, especially as they hint to a metaphor of weaving that our global societies are reluctant to recover.

In the context of Greek appraisal to episteme, subordinated arts as weaving do not announce any promising epistemic value. Thus the apodictic methodology of science uses it to appear as a high-level performance compared to the empirical operations carried out by domestic arts, which require that the agent quits the ideal realm and stains her hands for obtaining the best product in contact with the materials she has available. A well-known excerpt of Aristophanes' comedy Lysistrata praises the female arts of domestic weaving that does not meet the claims that the Athenian magistrate utters. Lysistrata's speech contains insightful remarks about how the domestic realm influence the public awareness about which kind of operations politics has to display. Lysistrata's description draws to the fact that before weaving a useful cloak, the weaver has to discard the unfit elements, the burrs and the parasites, splitting the people that openly contribute to the polis from those who have to be rejected, identified with 'civil rubbish'. In a quite similar approach to Pericles' logos epitaphios in the 2nd book of Thucydides History of the Peloponnesian War, Lysistrata's argument 
intertwines slaves and citizens, allies and aliens as necessary elements for weaving what she calls the citizenry's cloak, thus furnishing to the Greek appraisal of politics a confirmation of the benefits of an enlarged political participation.

The weaving image used by Lysistrata and later by Plato in Statesman as a pre-civil backbone made of shared habits and practices still resounds in Iris M. Young's description of solidarity, understood as a silent but highly effective bond that unfolds a network which gives shelter to both human doer and endurer. I suggest heeding to the model of social cooperation and to the account of responsibility entailed by the following excerpt by I. M. Young:

'As a term, and a concept, solidarity need not connote homogeneity or symmetry among those in relation. Some people use the term to imply identification with others or the unity of a group, but such usages can and should be challenged. As I am understanding it, solidarity is a relationship among separate and dissimilar actors who decide to stand together, for one another. Moreover, unlike brotherhood, which appeals to a natural origin in the unspoken mother, already there to be counted on, solidarity must always be forged and reforged. Solidarity is firm but fragile. It looks to the future because it must constantly be renewed' (Young 2013: 120).

As Young highlights in this text, it is a key challenge of our time to be able to let aside outdated mythical narrations of the past, fostering to set social bonds as solidarity through a vindication of plurality and heterogeneity, forestalling that the individual begins to feel nostalgic for belonging to the same tribe, clan or national family. Hence, the violence rooted in our Modern political tenets would be superseded by a sense of order that departs from non-violence as principle without fudging the troubles raised by contingent outburst of social hate and aggression.

\section{THE GLOBAL SUCCESS OF ALT-RIGHT POLITICS: A CULTURAL STRUGGLE}

The challenges raised by the claim of interdependence display a deep transformation of the way democratic societies tackle violence. Therefore, to increase the chances that a society has for experiencing our reciprocal vulnerability and our dependence from others appears as a useful means for becoming aware of the material conditions that make a social community liveable and aware of the tasks that the commonwealth self has still to fulfil. Hereby the assumption of plurality becomes the centre of the discussion, as it has to move from the space identified with the dreaded marginality and other elements that the communities usually try to oust from their boundaries, for becoming the core of a new conception of social dynamics and political activity. In this context the last decade provides, not only in Europe, but especially in the American continent, telling examples of a right populist wave spreading a notion of difference that, as in Schmitt's writings, glitches all the connections between politics and pluralism. Actually, difference becomes in these approaches a pre-political condition of political map, thus determining which sort of encounters with the other a community will accept as normative.

Gambetti has carried out an accurate survey of essays supporting Alt-Right claims, drawing as a conclusion that the cultural struggle is the benchmark of these reactionary populist global tendencies. Moreover, she yields remarks akin to the conclusions drawn by Vladimir Safatle in the context of Bolsonaro's autocratic model of politics, which raises xenophobia, misogyny and militarism to the highest values of a community. According to Safatle, an anti-predicative model of recognition would mean a completely opposed account to Alt-Right models 
of the bonds expected to connect the state with the citizenship. ${ }^{4}$ Safatle's argument helps to notice that the anxiety even of democratic states to control all the features of social life obeys to the desire to design it according to the frame of white racialism. Thus the autocracy model of power pursued by Alt-Right political forces requires a previous cultural struggle that expects to homogenize social normativity. I would like to quote a remark contained in a forthcoming paper by Gambetti, which focuses on the negation of political action as acceptation and respect of all differences which Alt-Right deep cultural transformation entails:

\begin{abstract}
"In Far Right texts and discourses "difference" does not refer to any action-based, performative or creative individuation, but to a fixed and axiomatically constructed boundary. On the one hand, the Far Right craves for difference as opposed to the uniformity imposed by the market, but cannot construe of any other difference than that related to identity. On the other hand, it craves for identity as opposed to constant fluctuation and differentiation through the impersonal laws of the market, but cannot construe of any identity other than that which is axiomatic. The risks associated with neoliberal discourses of freedom are projected onto an alien or enemy that then comes to epitomize risk' (Gambetti forthcoming: 11).
\end{abstract}

Gambetti moves in this text from Arendt's claim that difference does not work as a menace that should blow up the safeguards of the community. In my view, her analysis of an essentialist conception of identity and difference casts light over a key operation driven by Alt-Right social revolution. It is a matter of fact that as a reaction to the precarity and social suffering triggered by neoliberal economic and social dynamics, the projection of migrant people as a plague that jeopardizes the already limited access of native people of a country to public services and commodities has displayed a cultural battlefield in South Europe. Yet such an account of global migration is unable to set up a new political contract, encouraging national states to sign an interdependency agreement at a global scale. On the contrary, the motto 'walled states, waning sovereignty', coined by Wendy Brown (2010), resonates in our ears as a phrase full of sound and fury, unfit to re-politicize the states-of-nature that loom our everyday civil life. Thus, naturalized stages opposing friends and foes act as a simplistic but also devastating pattern that stealthily hollows up political agency, which depends on a 'parity of participation', borrowing Nancy Fraser's well-known claim. Hence, staging hostility - to social groups, to foreigners, to outcast people - as the highest expression of the general will drains the contents of political action, gearing the public focus to a psychoanalytical scenario, where the other always embodies the ballast of all our frustration and disappointment. Hereby nihilist narcissism disguises itself as a saviour table for weary and waning low middle-class people.

Gambetti has also addressed this paradoxical movement with remarks that trouble us insofar as they point out the tasks still to fulfil by progressive political forces. ${ }^{5}$ As an outcome of this perverse Alt-Right re-politicization, I would also agree with Gambetti as she states that participation should not be worshipped, as its emergence were expected to automatically improve and strengthen the public sphere. On the contrary, the forms of social and political engagement promoted by Alt-Right movements also contributed to swamp the public discourse

3 See Safatle (2016: 297): 'It may even be suggested that problems connected to redistribution should be sufficiently regulated within the juridical ordering, so that processes of recognition could develop within a zone of indifference in which legal structures had been rendered inoperative.'

5 Gambetti 2018: 2: 'I propose instead that we comprehend the Alt-Right as a specific mode of re-politicization in an age of neoliberal depoliticization, but one that exacerbates the problems plaguing political systems instead of effectively overcoming them.' 
into myriads of fake news, false alarms and overstaged affronts. In my view, other reflections of Gambetti about regressive populist politics cast light over the impact that the circuits of actions and public performances show on the social epistemic values regarding which issues matter and which ones should have priority over others:

'The idea that the neoliberal economy would push back the state with its centralized mechanisms of rule and replace them with more participatory forms of governance has proven to be extremely ambivalent. Citizens have indeed become "more participative", but more in policing dissent, handing out guilt verdicts, patrolling the country's borders, and keeping class conflict at bay, than in effectively exercising power' (Gambetti 2018: 5).

Tuning in with Wendy Brown's observations about the anthropological revolution set up by the 'stealthy' neoliberal revolution, Gambetti bothers in some way the quiet conscience of European middle class expectations about institutional representation, as it urges us to suspect about the high positive value that, for example, Arendt ascribes to human appearance through action. Recent social movements in Europe and America proved that not any popular mobilization endorses progressive goals. Claims raised in squares, arenas and roundsabout often avow their will to cleave the alleged right side of society - considered the authentic habitants of a territory, the good Europeans or good Americans - from the wrong side. To unfold this gap requires a huge waste of human energies, which instead of engaging in this task could address challenges as multicultural integration in democratic societies. Yet populist right movements boost that the people consecrate their efforts to build protective walls against the sources of danger they have been instructed to fear.

Put differently, as the politicization of the common withers out, psychic energies that we thought overcome by cultural development and education return to our lives as an ominous nightmare. Hence, as it is always the case of dreams and nightmares, these expressions of the mind should not be discarded by social science as a symptom of a callow mind. On the contrary, the phantom construction of otherness fulfils a helpful function for appeasing grievances left unattended, although this transaction reveals itself harmful for the stability of the community as a whole. Thus Freud's death drive impends and hampers social life in this sort of far-fetched conception of the community, insofar as according to it Alt-Right political forces move the citizenry to feel relieved as they are authorized to decide between the lives that matter and those that deserve neither solidarity nor trust, hence renouncing to demand any public accountability for high unemployment rates, fall in purchasing power and public services in disrepair.

This is one of the most telling manifestations of populism, i.e. the use of gloom, resentment and hostility for fuelling bodily and discursive performances that aim to make of difference an objective evidence. In this vein, Gambetti finds in the Gilets jaunes rioting every Saturday in public space in Paris the embodiment of a craving for political participation felt by 'the part of those that have no part', even if this popular grievance flaunts a manifest detachment from social solidarity and democratic institutions (Z. Gambetti forthcoming: 14). In my view the Gilets jaunes wield power against the unjust requirements of neoliberal market, but they also perform the power they embody as a blunt and nihilistic mass, not as a society aware of the existence of several social groups living in it, provided with their own interests. Arendt may be cited as an author interested in the totalitarian elements entangled in the increasing of politics based on fear and hate. 


\section{CONCLUSIONS}

I would follow Gambetti as she argues that rioters manifested their refusal to be treated as a population, not accepting to be battered, abused and destined to live in cluttered lodges and in clear disarray. Yet, in my view, this irate mass raises extremely shallow political demands, which confirm that they disclaim any civil responsibility and political agency, showing their claim for being immediately relieved from the social suffering generated by neoliberal market. I do not appreciate in this mob the aim to gather people to attain common goals or the intention to transform precarity into civil and political recognition.

I perceive rather in their riotous spirit the dull assumption of a subordinated role, which authorizes the agent as victim to commit all kinds of misdeeds. ${ }^{6}$ Thus rebellion and immaturity overrun the space that should be occupied by discursive exchange and shared action, ruining the political hope still existing in European deep-damaged institutional structures. In a nutshell, the contemporary neofascism fostered by Alt-Right movements and parties discovered in the notion of victim a useful means to undo the claims that demanded political emancipation in last centuries. Thus they built up a dangerous surrogate to political consciousness, which replaces the struggle for political equality with scapegoat's deceiving images.

It is out of doubt that the high social impact achieved by Alt-Right motivates a deep reflexion on the causes that move the precarious working classes away from Leftist classical political parties. In my view, a key element of this breakup obeys to the fact that the Leftist discourse often outshines the scope of the transformations needed to fight against precarity, poverty and social exclusion. Yet Alt-Right movements affirm that an ambitious agenda of public expense does not meet the demands of the citizenry they acknowledge as genuine. Thus they try to legitimate economic cuts and sacrifices the unique means for improving the welfare of the nation, making exclusion and lack of solidarity a condition for strengthening the public wealth. On the contrary, to make interdependence a value might counteract emotions as fear and values as exclusion, making integration not just a moral goal, but also an ontological confirmation of the fact we all are earth dwellers. Only if contemporary societies become aware of the level of dependency that all nations and societies display, the focus on sovereignty as the highest political status might change, opening the path to more constructive multilateral political actions.

Received 28 December 2019

Received 11 February 2020

\section{References}

1. Brown, W. 2010. Walled States, Waning Sovereignty. New York: Zone Books.

2. Brown, W. 2006. 'American Nightmare. Neoliberalism, Neoconservatism, and De-Democratization', Political Theory 34(6): 690-714.

${ }^{6}$ I consider insightful Safatle's remark about the fading of the image of a political homogeneous mass as the key agent of politics and the bloom of the kratos to be assigned to the new demos. See Safatle (2019: 8): 'Adorno recalled once that the anticipation of the form of the reconciled society is an attempt against the reconciliation itself. For mutilated subjects that we cannot imagine what social freedom is without designing modes of organization that are proper to a situation of civil war like this that we live in our daily class struggles, in our struggles against state violence embedded in our liberal democracies. To keep silent about what will be the government of another kratos is not impotence, but trust on the plastic force of politics and its multiple localities'. 
3. Butler, J. 2017. Notes Toward a Performative Theory of Assemblies. Harvard: Harvard University Press.

4. Friberg, D. 2015. The Real Right Returns. London: Arktos.

5. Gambetti, Z. 'Immanence, Neoliberalism, Microfascism: Will We Die in Silence?', in The Non-Fascist Life, eds. R. Braidotti and R. Dolphijn (forthcoming).

6. Gambetti, Z. 2018. 'How "Alternative" is the Alt-Right?', in Critique and Praxis 13/13. Available at: https://blogs.law.columbia.edu/praxis1313/zeynep-gambetti-how-alternative-is-the-alt-right/ (accessed 15.09.2019).

7. Hawley, G. 2017. Making Sense of the Alt-Right. New York: Columbia University Press.

8. Jaeggi, R. 2018. Critique of Forms of Life. Transl. by C. Cronin. Cambridge (MA): Harvard University Press.

9. Main, T. J. 2018. 'The Rise of the Alt-Right'. Washington: The Brookings Institution.

10. Safatle, V. 2016. Grand Hotel Abyss. Desire, Recognition and Restoration of the Subject. Leuven: Leuven University Press, 271-300.

11. Safatle, V. Another Kratos for the Demos. Available at: https://www.celap.edu.rs/en/author/admin/ page/2/ (accessed 17.09.2019).

12. Salazar, P.-J. 2018. 'The Alt-Right as a Community of Discourse', Javnost - The Public 25/1-2: 135-143.

13. Schmitt, C. 2010. La tiranía de los valores'. Spanish transl. by A. Schmitt, ed. by M. Herrero. Granada: Comares.

14. Young, I. M. 2013. 'A Social Connection Model', in Responsibility for Justice, ed. I. M. Young. Oxford: Oxford University Press, 97-122.

NURIA SANCHEZ MADRID

\title{
Vertybių prievarta / prievartos vertybès. Alternatyvios dešinès kultūrinè kova
}

\begin{abstract}
Santrauka
Svarstoma, kaip šiandieninė alternatyvi dešinė konstruoja savo socialines ir politines vertybes. Pirmiausia svarstomos pačios vertybès, kurias alternatyvi dešinė paskutinį dešimtmetị propaguoja visame pasaulyje. Antra, gilinamasi, kaip šios politinès pakraipos atstovai komunikuoja su socialiai pažeidžiamiausiomis socialinėmis grupėmis, siekdami jas įtraukti ị savo rèméjų gretas, ir kaip jie kuria naują socialinès tvarkos modelį, pažeidžiantị žmogaus ir pilietines teises. Galiausiai aiškinamasi, kodẻl klasikinès kairiosios partijos patiria nesèkmę bandydamos atnaujinti dialogą su buvusiąja „darbininkų klase“. Svarstydama šiuos klausimus, straipsnio autore remiasi Zeynepos Gambetti ir Vladimiro Safatle’o tyrinejjimais, kuriuose pagrindinis dèmesys skiriamas populistiniu dešiniųjų partijų kultūrinei kovai visame pasaulyje.
\end{abstract}

Raktažodžiai: prievarta, suverenumas, tarpusavio priklausomybè, nesaugumas, liaudis, alternatyvi dešinè 